\title{
Early Childhood Anti-Violence Education in The Perspective of Psychology
}

\section{Eni Rosda Syarbaini}

Received: 20052016 / Accepted: 2505 2016 / Published online: 13122016

๑) 2016 Association of Indonesian Islamic Kindergarten Teachers Education Study Program

\begin{abstract}
Early age children is nation next generation. Government gives serious attention toward early childhood education which is pointed out by PP No. 60 th. 2013 about the integrative and holistic service of early childhood development. Children violence might be occurred everywhere, it could be in the family, on the street and children trafficking. Children violence is a social problem that has a big impact toward psychological, physical, mental, and the growth of children. To prevent this violence, government, society, teachers and parents must involve intensively. Government has issued the law no. 35 th. 2014 about children care. Early childhood must be protected from any kinds of violence. Education for early childhood must be done using learning approach through play games, interactive, children centered, and in joyful atmosphere.
\end{abstract}

Keywords fun education for early childhood, anti violence, psychology.

\begin{abstract}
A bstrak Anak usia dini adalah generasi penerus bangsa. Pemerintah memberikan perhatian yang serius terhadap pendidikan anak usia dini yang ditunjukkan dengan Peraturan Presiden Nomor 60 tahun 2013 tentang Pelayanan Pengembangan Anak Usia Dini Holistik Integratif. Kekerasan terhadap Anak dapat terjadi dimana-mana, seperti dalam lingkungan keluarga, di jalanan, dan perdaganagan anak. Kekerasan terhadap anak merupakan masalah sosial memiliki dampak besar terhadap psikologis, fisik, mental, dan tumbuh kembang anak. Untuk pencegahan kekerasan terhadap anak, dituntut peran aktif orang tua, pendidik, masyarakat, dan Pemerintah. Pemerintah menerbitkan Undang-Undang N omor 35 Tahun 2014 tentang Perlindungan Anak. Anak usia dini harus dilindungi dari segala bentuk kekerasan. Pendidikan Anak Usia Dini dilakukan dengan pendekatan belajar melalui bermain, interaktif, berpusat pada anak, dan dalam suasana yang menyenangkan.
\end{abstract}

Kata Kunci: PAUD M enyenangkan, Anti Kekerasan, Psikologi.

\section{Pendahuluan}

Kualitas sumber daya manusia merupakan faktor determinan bagi keberhasilan pembangunan dan kemajuan suatu bangsa. Dengan sumber daya manusia yang berkualitas, bangsa Indonesia diharapkan mampu bersaing di abad 21, suatu era ilmu pengetahuan yang sarat dengan beragam tantangan, keterbukaan, percepatan informasi dan teknologi bahkan kompetisi yang berdimensi global. Kondisi tersebut tentu saja mengharuskan adanya sumber daya manusia yang unggul (uberrmensch) partisipatoris, bermartabat dan berakhlak mulia.

Pengembangan sumber daya manusia haruslah merupakan suatu proses berkesinambungan sejak usia dini. Pendidikan anak usia dini merupakan pendidikan yang 
sangat mendasar dan strategis dalam pembangunan sumberdaya manusia. Masa usia dini 0-6 tahun merupakan periode emas (golden age) bagi perkembangan anak untuk memperoleh proses pendidikan. Pandangan tersebut tercantum pada Undang-Undang Nomor 20 Tahun 2003 tentang Sistem Pendidikan Nasional, karena anak pada usia tersebut dianggap sebagai masa anak mempersiapkan potensi fisik dan mental dalam menatap masa depannya.

U paya dan perhatian pemerintah terhadap pengembangan Anak Usia Dini semakin serius, hal ini ditunjukkan dengan Peraturan Presiden Republik Indonesia Nomor 60 Tahun 2013 Tentang Pengembangan Anak Usia Dini Holistik Integratif. Pengembangan Anak Usia Dini Holistik Integratif meliputi: pelayanan Gizi, pelayanan Kesehatan, pelayanan Pendidikan, pelayanan Pengasuhan, dan pelayanan perlindungan. Dalam rangka mendukung penyelenggaraan PAUD berkualitas, I bu N egara I riana Joko W idodo bertempat di Taman M ini Indonesia Indah, pada tahun 2014 telah mencanangkan "Gerakan Nasional PAUD Berkualitas" (Direktorat PAUD, 20014). Selanjutnya dalam mewujudkan pelaksanaan Pendidikan A nak Usia Dini berkualitas, Kementerian Pendidikan dan Kebudayaan dalam Rencana Pembangunan Jangka M enengah 2015-2019 menekankan tentang pentingnya "Peningkatan Akses dan Kualitas PAUD Secara "H olistik Integratif" sebagai pondasi terwujudnya pendidikan dasar 12 tahun yang berkualitas (Depdiknas, 2014).

Dalam menunjang Peraturan Pemerintah Nomor 60 Tahun 2013 di atas, Komisi Perlindungan Anak Indonesia (KPAI) Pusat sedang mempersiapkan masuknya mata kuliah Perlindungan A nak pada semua Fakultas IImu Pendidikan yang ada di Indonesia. Rencana baik ini sudah dibicarakan pada focus group discussion Dekan Fakultas IImu Pendidikan di Jakarta pada O ktober 2015 bertempat di Kantor KPAI Pusat.

Target agenda pendidikan 2030 untuk Pendidikan Anak Usia Dini (PAUD) adalah "memastikan seluruh anak laki-laki dan perempuan memperoleh akses terhadap perkembangan, perawatan, dan pendidikan Pra-SD (PAUD) yang bermutu untuk menjamin kesiapan memasuki pendidikan dasar (Direktorat PAUD 2015). Saat ini Indonesia juga sedang menyongsong menjadi "Center of Early Childhood Care Education and Parenting SEAMO CECEP Tahun 2017." Kenyataan yang ada sekarang, kekerasan terhadap A nak U sia Dini terjadi dimana-mana yang menimbulkan dampak yang kompleks yang menimbulkan penurunan kualitas hidup anak yang berada dalam proses tumbuh kembang.

\section{Anak Usia Dini}

M asa usia dini (0-6 tahun) merupakan periode emas ( golden age) yang sangat menentukan bagi anak dalam mengembangkan potensinya. Periode ini adalah tahun-tahun berharga bagi seorang anak untuk mengenali berbagai macam fakta di lingkungannya sebagai stimulan terhadap perkembangan kepribadian, psikomotor, kognitif, bahasa maupun sosial.

Berdasarkan hasil penelitian, perkembangan intelektual anak terjadi sangat pesat pada awal kehidupan anak. Sekitar 50\% variabilitas kecerdasan orang dewasa telah terjadi ketika anak 
berumur 4 tahun, $80 \%$ telah terjadi ketika berumur 8 tahun, dan mencapai titik kulminasi ketika anak berumur sekitar 18 tahun (Keith Osbord at.al dalam Diana M utiah: 2010). Hal ini berarti bahwa perkembangan yang terjadi dalam kurun waktu 4 tahun pertama sama besarnya dengan perkembangan yang terjadi pada kurun waktu 14 tahun berikutnya.

Periode emas ini merupakan periode kritis bagi anak yang merupakan periode khusus ketika perkembangan biologis anak berada pada tahap prima untuk mengembangkan sruktur syaraf dan keterampilan-keterampilan yang dipengaruhi oleh stimulus yang tepat. Anak juga berada pada kemampuan prima untuk mengendalikan emosi dan kebiasaan untuk bereaksi terhadap pengalaman baru yang dpierolehnya. Dimana kemampuan yang diperoleh pada periode ini sangat berpengaruh terhadap perkembangan periode berikutnya hingga masa dewasa (Fasli Jalal, 2009: 28). Sementara masa emas ini hanya datang sekali, sehingga apabila terlewat berarti habislah peluangnya. Untuk itu pendidikan untuk usia dini dalam bentuk pemberian rangsangan-rangsangan (stimulasi) dari lingkungan terdekat sangat diperlukan untuk mengoptimalkan kemampuan anak.

Perididikan A nak U sia Dini sejalan dengan apa yang dirumuskan UNESCO. Kompetensi pendidikan yang dirumuskan oleh UNESCO yang menyatakan bahwa pendidikan adalah serangkaian aktivitas untuk menanamkan kecakapan untuk mengetahui (to know), kecakapan bagaimana berbuat (to do) dan kecakapan untuk hidup (to be), dan kecakapan hidup bersama (to live to gather). Hal ini berarti bahwa perkembangan yang terjadi pada periode emas ini merupakan periode kritis bagi anak, dimana perkembangan yang diperoleh pada periode ini sangat berpengaruh terhadap perkembangan selanjutnya.

Penanganan serta pemberian rangsangan yang tepat dan sesuai akan sangat baik untuk menentukan kualitas sumber daya produktif di masa mendatang. Pendidikan untuk usia dini dalam bentuk pemberian rangsangan-rangsangan (stimulasi) dari lingkungan terdekat sangat diperlukan untuk mengoptimalkan kecerdasan yang dimiliki anak.

\section{Kekerasan pada Anak Usia D ini}

Pemerintah memberikan perhatian yang serius terhadap perlindungan anak dengan adanya Undang-U ndang Republik Indonesia Nomor 35 Tahun 2014 tentang Perubahan A tas UndangUndang N omor 23 Tahun 2002 tentang Perlindungan Anak.

Undang-Undang Perlindungan Anak, Pasal 1 ayat 1 menyatakan bahwa anak adalah seseorang yang belum berusia 18 tahun, termasuk anak yang masih dalam kandungan. Selanjutnya pasal 1 ayat 2 menyatakan bahwa perlindungan anak adalah segala kegiatan untuk menjamin dan melindungi anak dan hak-haknya agar dapat hidup, tumbuh, berkembang, dan berpartisipasi secara optimal sesuai dengan harkat dan martabat kemanusiaan, serta mendapat perlindungan dari kekerasan dan diskriminasi.

Kasus kekerasan terhadap anak adalah permasalahan yang cukup kompleks, merupakan masalah sosial yang memiliki dampak negatif yang serius. Baik bagi korban maupun lingkungan sosialnya. Bagi korban anak akan menimbulkan dampak besar pada aspek tumbuh kembang 
anak baik secara fisik maupun psikologis terutama trauma psikologis yang berdampak pada penurunan kualitas hidup anak yang berada dalam proses tumbuh kembang antar usia 0-18 tahun.

Kekerasan pada anak setiap tahun semakin meningkat. KPAI mengungkapkan data kekerasan terhadap anak dan layanan pengaduan dari 30 provinsi di Indonesia (http://www.kpai.go.id). Pada tahun 2006 jumlah pelanggaran hak anak yang terpantau sebanyak 13.447.921 kasus, tahun 2007 sebanyak 40.398.625 kasus. Pada Januari-Juni 2008 sebanyak 12.726 anak menjadi korban kekerasan seksual dari orang terdekat mereka seperti; orang tua kandung/tiri/angkat, guru, paman, kakek, dan tetangga. Beberapa bulan terakhir ini, pemberitaan media massa sangat mengejutkan kita.

Kekerasan pada anak usia dini tidak hanya terjadi di dalam lingkungan keluarga atau di rumah. Akhir-akhir ini diketahui dari gencarnya pemberitaan media masa menunjukkan bahwa kekerasan pada anak usia dini dapat terjadi dimana saja dan dengan berbagai macam kekerasan. Bentuk-bentuk kekerasan pada anak dalam artikel ini dibatasi pada 6 (enam) bentuk kekerasan, yaitu: kekerasan fisik, kekerasan karena diabaikan, kekerasan seksual, kekerasan psikis, kekerasan ekonomi, dan kekerasan perdagangan anak. Masing-masing bentuk kekerasan memiliki faktor pemicu dan konsekuensi yang berbeda-beda.

Kekerasan fisik adalah apabila anak-anak disiksa secara fisik atau kekerasan dilakukan dengan sengaja sehingga terdapat cedera yang berbekas pada badan anak akibat dari kekerasan. Bentuk kekerasan fisik ini adalah: dianiaya diluar batas: dipukuli, dijambak, ditendang, diinjak, dicubit, dicakar, dijewer, distrika, disiram air panas, dan sebagainya.

Kekerasan karena diabaikan menurut U ndang-U ndang Perlindungan A nak disebut A nak Terlantar, yaitu anak yang tidak terpenuhi kebutuhannya secara wajar, baik fisik, mental, spiritual, maupun sosial, sehingga anak terpaksa menjaga diri sendiri dan menjadi pengemis atau anak jalanan.

Kekerasan seksual adalah kegiatan atau aktivitas seksual yang dilakukan oleh orang dewasa atau oleh anak yang lebih besar terhadap anak, juga terlibat atau ambil bagian, melihat aktivitas yang bersifat sek dengan tujuan pornografi, gerakan badan, dan film. Bentuk kekerasan sek ini adalah: diperkosa, disodomi, diraba-raba alat kelaminnya, diremas-remas payudaranya, dicolek pantatnya, diraba-raba pahanya, dipaksa melakukan oral sek, dijual pada mucikari, dipaksa menjadi pelacur, dipaksa bekerja diwarung remang-remang, dan pelecehan seksual lainnya.

Kekerasan Psikis adalah perlakuan atau gangguan yang keterlaluan yang menimbulkan gangguan psikologi. emosi, dan mental anak. Bentuk kekerasan psikis ini adalah: dihina, dicaci maki, diejek, dipaksa melakukan sesuatu yang tidak dikehendaki, dibentak, dimarahi, dihardik, diancam, dan sebagainya. Kekerasan psikis dalam keluarga penyebabnya bisa pola asuh otoriter dan orang tua yang lagi stres.

Kekerasan ekonomi adalah pemaksaan terhadap anak untuk melakukan pekerjaan dengan tujuan mendapatkan keuntungan. Bentuk kekerasan ekonomi adalah: dipaksa bekerja 
menjadi pemulung, dipaksa mengamen, dipaksa menjadi pembantu rumah tangga, dipaksa mengemis atau dipaksa untuk bekerja mencari nafkah diusi yang belum sepatutnya.

Kekerasan perdaganagan anak adalah tindakan perekrutan, transportasi, transfer, penyembunyian atau penerimaan seseorang anak untuk maksud eksploitasi "memperdagangkan manusia" atau bentuk pemaksaan lainnya, seperti penculikan, pemalsuan, penipuan, penyalahgunaan kekuasaan atau penyalahgunaan posisi, menerima pembayaran, keuntungan, untuk mendapatkan izin dari orang yang memegang kendali atas orang lain.

Semua anak laki-laki maupun perempuan beresiko menjadi koban perdagangan karena anak lebih rentan dibandingkan orang dewasa. A nak sering dianggap lebih lemah, baik secara fisik maupun mental.

\section{Kebutuhan dan Perkembangan Anak dari Perspektif Psikologi}

Perkembangan anak dipengaruhi oleh sistem interaksi yang kompleks dengan berbagai tingkatan lingkungan sekitarnya. Lingkungan anak merupakan rangkaian struktur dari interaksi yang saling berhubungan antara di dalam dan di luar rumah dan menjadi penggerak perkembangan anak (Urie Bronfenbrenner dalam Fasli Jalal 2009). Hubungan anak dengan orang tua dan anggota keluarga, yaitu kakak dan adik kandungnya, teman sebaya, nilai-nilai budaya, adat kebiasaan dimana seluruh sistem ini berpengaruh terhdap perkembangan anak. Perkembangan anak ditentukan oleh apa yang dialami anak dan dalam situasi seperti apa anak menghabiskan waktunya. Dalam hal ini meliputi jumlah dan kualitas interaksi anak dengan keluarganya, dan teman-teman sebaya.

Selanjutnya pakar psikologi Maslow mengemukan hierarki kebutuhan manusia yang harus dipenuhi meliputi tujuh tingkat kebutuhan, yaitu: kebutuhan fisiologis, kebutuhan rasa aman, kebutuhan kasih sayang, kebutuhan penghargaan, kebutuhan ilmu pengetahuan, kebutuhan estetika, dan kebutuhan aktualisasi diri (Martini Jamaris, 2013). Pada anak anak usia dini, kebutuhan kasih sayang merupakan kebutuhan mendasar. Kasih sayang merupakan emosi positif yang sangat penting keberadaannya, ia menjadi dasar berbagai macam perilaku emosi dan kepribadian yang sehat. Hasil penelitian menunjukkan, bahwa kehangatan dan afeksi yang diberkan Ibu kepada anak akan berpangaruh pada perkembangan anak selanjutnya (Ella Yulaelawati, 2014). Kedekatan emosi yang kuat anak dengan orang tua, guru, dan orang dewasa lain, akan berpengaruh pada perkembangan anak secara intelektual, emosional, sosial, dan moral.

Emosi adalah perasaan yang ada dalam diri anak. Emosi merujuk pada suatu perasaan atau pikiran-pikiran khas, suatu keadaan biologis dan psikologis serta serangkaian kecenderungan untuk bertindak (Goleman, dalam Gotmann, 1998). Perasaan senang, marah, takut, dan sedih merupakan basic emotions (Stewar at all, dalam Ali Nugraha, 2007). Emosi berperan dalam perkembangan anak yang merupakan bentuk komunikasi untuk dapat menyatakan segala kebutuhan dan perasaannya pada orang lain dan mengenal berbagai persaan 
orang lain. Selain itu emosi dapat mempengaruhi interaksi sosial anak melalui reaksi-reaksi yang ditampilkannya. Sehingga dapat mempengaruhi kepribadian dan penyesuaian diri anak dengan lingkungan sosialnya.

Interpersonal yang sangat kuat akan dapat meningkatkan respon anak terhadap lingkungan fisik dan sosial. Stimulasi yang menyenangkan sangat diperlukan oleh anak untuk merasa nyaman dan merasa dicintai oleh lingkungannya.Interaksi anak dengan orang tua dan orang dewasa akan mengembangkan kemampuan sosialisasi anak. Perkembangan kemampuan sosialisasi menjadi prasyarat berkembangnya potensi lain, seperti: perkembangan bahasa, kognitif, konsep diri, kepercayaan diriemosional, dan kemandirian. (Peaget dalam Mary Mayesky, 2012).

\section{Dampak Kekerasan Terhadap Anak dalam Tinjauan Psikologi}

Setiap anak ingin merasa disayangi oleh orang tua, keluarga, guru, dan oleh setiap orang yang dikenalnya. Kekerasan terhadap anak akan menimbulkan trauma psikologis, anak akan menderita batinnya. Anak akan merasa sedih, gelisah, gangguan mental, dan kelakuannya mungkin menjadi nakal. Tekanan emosi akan mempengaruhi dan menghambat konsentrasi, kemampuan mengingat, penalaran, motivasi, minat, kepercayaan diri, penyesuaian diri, sikap dan ekspresi psikologis lainnya.

Kemampuan konsentrasi formal anak usia dini masih pendek. Sesuai dengan karakteristiknya, Anak sangat mudah beralih perhatian dan minat.Anak yang terganggu emosinya akan kehilangan konsetrasi. Pada kondisi ini, Anak akan kacau sekali dalam melakukan kegiatan terutama saat ia melakukan kegiatan belajar. Semangkin tinggi emosi negatif, semakin sulit mengembalikan diri pada konsentrasi kegiatan. Bahkan pada tingkatan tertentu seseorang tidak dapat berkonsentrasi sama sekali.

Gangguan emosi yang berlangsung lama, akan mengakibatkan kemampuan mengingat dan daya pikir anak akan sangat terhambat. Potensi mengingat dalam memori anak yang sering mengalami ketegangan emosi tidak akan berkembang secara baik. Mustafa dalam Nugraha.meyakini bahwa anak yang mengalami ketegangan emosi dan diikuti dengan stress akan mengurangi kemampuan mengingatnya $80 \%$. Jangankan mengingat yang sedang dan yang akan dipelajari anak, yang telah dihafal pun akan lupa dan mungkin hilang dari memorinya (Nugraha \& Yeni Rachmawati, 2007: 39).

Pengalaman traumatik akibat kekerasan akan mempengaruhi keseluruhan pribadi anak. Bagaimana anak berpikir, belajar, mengingat, mengembangkan persaan diri sendiri, semuanya tidak dapat dilepaskan dari pengalaman traumatiknya. Keadaan ini akan mempengaruhi kepribadian anak kelak. Pengalaman-pengalaman masa kecilnya adalah pengalaman yang paling berharga dalam hidupnya.D an pengalaman ini dijadikan referensi dalam mengatasi problemaproblema hidup ketika mereka dewasa kelak. Anak akan selalu merasa bersalah sehingga memiliki konsep diri yang negatif. 
Dampak sosial dan emosional yang mungkin dialami oleh anak korban perdagangan adalah anak mengalami perasaan kehilangan kontrol dan kurangnya rasa aman. Hilangnya kepercayaan, karena anak korban perdagangan biasanya dibohongi, stigma sosial, dan rasa malu, sehingga anak sulit mempercayai orang lain atau membina hubungan dengan lain. Selain itu, Anak korban perdagangan memiliki rasa rendah diri dan hilangnya kepercayaan diri, mereka juga mengalami respon emosional yang kuat, seperti kemarahan, histeria, mudah menangis, mempunyai perasaan tertekan merasa bersalah yang menghantui pikiran korban. A kibat dari dampak kekerasan terhadap anak usia dini pada akhirnya Anak tidak dapat mencapai prestasi akademik yang baik.

\section{Pendekatan Pendidikan Anak Usia Dini}

Merujuk pada Peraturan Menteri Pendidikan dan Kebudayaan Nomor 137 Tentang Standar Nasional Pendidikan Anak Usia Dini Pasal 13, ayat 1 menyatakan bahwa pelaksanaan pembelajaran dilakukan melalui bermain secara interaktif, inspiratif, menyenangkan, kontekstual, dan berpusat pada anak untuk berpartisipasi aktif serta memberikan keleluasaan bagi prakarsa, krativitas, dan kemandirian sesuai dengan bakat, minat, dan perkembangan fisik serta psikologis anak .

Dalam menindaklajuti Standar Nasional Pendidikan Anak Usia Dini, maka pendekatan pendidikan anak usia dini meliputi: berorientasi pada kebutuhan anak, berorientasi pada perkembangan anak, belajar M elalui bermain, pembelajaran aktif, inovatif, kreatif, efektif, dan menyenangkan (PAIKEM), pembelajaran terpadu, dan pengembangan keterampilan hidup.

\section{Upaya Pencegahan}

H arus kita sadari bersama bahwa pada dasarnya semua pihak dapat berperan untuk mencegah terjadinya kekerasan pada anak usia dini demi terwujudnya perkembangan anak yang positif. Anak membutuhkan stimulasi yang menyenangkan untuk anak merasa nyaman dan merasa dicintai oleh lingkungannya. Hillary Clinton (dalam Fasli Jalal, 2009: 24) mengemukakan pentingnya totalitas dari lingkungan anak untuk memberikan stimulasi pada anak yang disebut "it takes a village to raise a child" (diperlukan orang sekampung untuk membesarkan seorang anak). Pihak-pihak yang berperan dalam mencegah kekerasan terhadap anak adalah orang tua, pendidik, masyarakat, dan pemerintah.

Orang Tua harus lebih memperhatikan kehidupan anaknya. Orang tua dituntut kecakapannya dalam mendidik dan menyayangi anak-anaknya. Orang Tua harus menyadari sepenuhnya bahwa perilaku mereka merupakan model rujukan bagi anak-anaknya. Sehingga mereka mampu menghindari perilaku yang kurang baik.

Pendidik harus memahami kondisi siswa, serta sikap arif, bijaksana, dan toleransi sangat diperlukan. Pendidik disarankan lebih efektif memberikan edukasi dan informasi kepada Anak Usia Dini mengenai perlindungan diri untuk segera menceritakan pada orang tua dan guru 
terhadap apa yang dialaminya. Karena orang tua dan guru akan selalu menolong mereka. Selalu tumbuhkan percaya diri dan rasa berani mereka.

Orang tua dan pendidik harus menjalin komunikasi yang efektif. Pendidik disarankan untuk banyak memberikan edukasi dan informasi kepada orang tua mengenai kekerasan dan dampaknya pada anak. Sampaikan pada orang tua bahwa kekerasan pada anak menimbulkan dampak serius trauma psikologis, yang mengganggu tumbuh kembang dan masa depan anak.

Diperlukan kesadaran dan kerja sama dari berbagai elemen masyarakat untuk turut memberikan nuansa pendidikan positif bagi anak-anak. Harus ada kontrol dari pemuka masyarakat terhadap aktivitas di lingkungan masyarakat yang berdampak timbulnya kekerasan terhadap anak.

Prinsip penanganan kasus kekerasan anak adalah non diskriminasi, kepentingan terbaik anak, menghormati pendapat anak, mengutamakan hak anak demi kelangsungan hidup dan tumbuh kembang anak. Pemerintah harus menjamin masa depan anak-anak sebagai generasi penerus. Pemerintah dan masyarakat harus berperan aktif dalam menangani kasus kekerasan terhadap anak dengan melakukan langkah-langkah:

1. Pemberian jaminan dan perlindungan kepada anak-anak yang membutuhkan perlindungan khusus untuk terjaminnya hak-hak anak.

2. M engembangkan sistem informasi yang menyediakan data dan informasi tentang kekerasan terhadap anak.

3. Meningkatkan responsivitas semua pihak terkait, baik pemerintah maupun masyarakat dalam upaya pencegahan pelanggaran hak anak dan perlindungan bagi anak-anak yang membutuhkan perlindungan khusus.

\section{Simpulan}

Kekerasan pada anak usia dini akan menimbulkan dampak psikologis antara lain adalah: anak merasa sedih, gelisah, mengalami trauma psikologis, tekanan emosi sehingga sulit berkonsentrasi, kemampuan mengingat rendah, penalaran rendah dan kurang Aktivitas. Berdampak terhadap motivasi, minat, kepercayaan diri, penyesuaian diri, konsep diri, sikap dan ekspresi psikologis lainnya. A nak yang mengalami tekanan emosi yang lama akan menurunkan kemampuan mengingat. Bagi korban perdagangan, anak merasa kehilangan kontrol dan perasaan kurang aman. Anak korban perdagangan memiliki rasa rendah diri dan hilangnya kepercayaan diri, mengalami respon emosional yang kuat, seperti kemarahan, hysteria, mudah menangis, mempunyai perasaan tertekan merasa bersalah yang menghantui pikiran korban. Dapat dikatakan bahwa tekanan emosi yang dialami anak akibat kekerasan akan berdampak negatif terhadap kepribadian anak akibatnya Anak tidak dapat berprestasi.

A nak usia harus dilindungi dari segala bentuk kekerasan. Pendekatan penanganan adalah: meningkatkan peran aktif Orang tua, Pendidik, Masyarakat, dan Pemerintah. Prinsip penanganan kasus kekerasan anak adalah non diskriminasi, kepentingan terbaik anak, 
menghormati pendapat anak, mengutamakan hak anak demi kelangsungan hidup dan tumbuh kembang anak. Dan Pendidikan dilakukan melalui bermain secara interaktif, inspiratif, menyenangkan, kontektual, dan berpusat pada anak untuk berpartisipasi aktif serta memberikan keleluasaan bagi prakarsa, kreativitas, dan kemandirian sesuai dengan bakat, minat, dan perkembangan fisik serta psikologis anak.

\section{Daftar Pustaka}

Depdiknas. 2014. Rencana Strategis Departemen Pendidikan Nasional tahun 2015-2019. Departemen Pendidikan Nasional Jakarta.

Jalal, Fasli. 2009. Pengaruh Gizi dan Stimulasi Psikososial Terhadap Pembentukan Kecerdasan Anak Usia Dini; Agenda Pelayanan Tumbuh Kembang anak Holistik-Integratif. Padang: U niversitas A ndalas.

Jamaris, M artini. 2013. Orientasi Baru Dalam Psikologi Pendidikan. Jakarta: Ghalia Indonesia. Mayesky, Mary. 2012. Creative Activity for Young Children. Amerika: Wadsworth Cengage Learning,

M utiah, Diana. 2010. Psikologi Bermain Anak U sia Dini. Jakarta: Kencana Grada media group. Nugraha, Ali dan Yessy Rahmawati. 2007. Metode Pengembangan Sosial Emosional. Jakarta: U niversitas Terbuka.

Sujiona, Yuliani N urani. 2012. Konsep Dasar Pendidikan Anak U sia Dini. Jakarta: PT INDEKS. 
